WIDER Working Paper 2016/9

\title{
Political economy of Nigerian power sector reform
}

Eric Kehinde Ogunleye*

March 2016 
Abstract: The Nigerian power sector reform is necessitated by the chronic poor performance of the sector and has as its compass the 2005 Electric Power Sector Reform Act and the Roadmap for Power Sector Reform 2010. Implementing reform has resulted in significant progress that includes unbundling and privatization of the long-standing government-owned monopoly in the power sector. The paper provides a comprehensive assessment of the reform, isolating the major challenges facing it, and focusing on political economy developments surrounding regulatory, institutional, legislative, and fiscal issues, with mainstreaming clean renewable energy being the main theme running through the analysis.

Keywords: Nigeria, political economy, power sector reform, privatization, renewable energy JEL classification: L94, L98, Q43, Q48

Acknowledgements: I appreciate the support of UNU-WIDER and JISEA/NREL through the project on'Political Economy of Clean Energy Transitions'. Comments from participants at the project workshop held in Golden, Colorado and of two anonymous referees are gratefully acknowledged.

* African Development Bank, Nigeria Country Office, Abuja, Nigeria, eric.oleye@gmail.com.

This study has been prepared within the UNU-WIDER project on 'The Political Economy of Clean Energy Transitions'.

Copyright (C) UNU-WIDER 2016

Information and requests: publications@wider.unu.edu

ISSN 1798-7237 ISBN 978-92-9256-052-2 https://doi.org/10.35188/UNU-WIDER/2016/052-2

Typescript prepared by Sophie Richmond.

The United Nations University World Institute for Development Economics Research provides economic analysis and policy advice with the aim of promoting sustainable and equitable development. The Institute began operations in 1985 in Helsinki, Finland, as the first research and training centre of the United Nations University. Today it is a unique blend of think tank, research institute, and UN agency - providing a range of services from policy advice to governments as well as freely available original research.

The Institute is funded through income from an endowment fund with additional contributions to its work programme from Denmark, Finland, Sweden, and the United Kingdom.

Katajanokanlaituri 6 B, 00160 Helsinki, Finland

The views expressed in this paper are those of the author(s), and do not necessarily reflect the views of the Institute or the United Nations University, nor the programme/project donors. 
The Nigerian energy sector is currently undergoing one of the most ambitious, comprehensive, and bold reforms in the history of Africa. The ultimate aim is to privatize all power assets with a view to ending the country's chronic power shortages and long-standing monopoly of the sector by the state-owned power entity. The reform is based on the 2005 Electric Power Sector Reform Act, 2010 Roadmap for Power Sector Reform, and subsequently the 2013 Roadmap for Power Sector Reform Revision 1, among several other policy documents. While the Act provides a legal backing for the reform, the roadmaps serve as instruments for fast-tracking the proposed fundamental changes to the ownership, control, and regulation of the sector as envisaged in the Act and ensure these are achieved and realized, especially for the ultimate benefit of electricity users.

The Act focuses on creating a regulatory agency that would serve as the umpire for ensuring effective enforcement and compliance with the rules of the game in the electricity sector. It emphasizes privatization of a hitherto government-owned electricity company that has monopolized electricity generation, distribution, and transmission for decades. Through this action, the reform seeks to remove obstacles to private sector investment in this critical sector. It also attempts to improve energy independence and diversify energy sources towards cleaner energy such as solar, geothermal, and wind. The objectives of the reform include highly ambitious targets for the power sector. It is projected that power generation would reach over 13,000 megawatts (MW) by 2015 and 40,000 MW by 2020. To reach these targets, efforts are being made to scale up and maintain a steady pace and timely implementation of the reforms. One specific proposed strategy that would promote technology-specific incentives in the face of power sector privatization is the design of a feed-in tariff system which allows producers of renewable energy to sell their power to the national power grid at considerably higher prices than those generating power through the conventional sources of coal, gas, and hydro. Added to this are the guaranteed purchase of energy by the Nigerian Bulk Electricity Trading company (NBET) and a five-year tax-free period for investment in renewable energy.

The reform was conceived out of obvious challenges facing the country's energy sector with serious negative effects on business (Figure 1). Power outage is a common and daily experience; Nigeria is one of the countries with the lowest electricity consumption per capita in the world at around 100 kilowatt-hour ( $\mathrm{kWh}$ ) per annum. Installed capacity remains low at around 8,000 MW, out of which only 4,000 MW is operable and less than 2,000 MW available to generate energy. The gross inadequacy of energy generation becomes glaring when compared with South Africa's almost 5,000 kWh per capita. Indeed, 60 per cent of the time, there is no access to electricity in Nigeria (Aliyu et al. 2013). The energy challenge is so perennial that the acronym for the erstwhile state-owned electricity company, NEPA (National Electric Power Authority), was sarcastically rendered as 'Never Expect Power Always'. When the name was changed to PHCN (Power Holding Company of Nigeria) it was twisted to mean the 'Problem Has Changed Name'. Nigeria's growth potentials will remain unrealized if the power sector challenges are not fixed.

It is noteworthy that modest progress has been recorded in the course of implementing the power sector reform. First, the hitherto state-owned monopoly in the electricity sector-NEPA and later PHCN-has been unbundled, giving way to the emergence of 11 distribution companies, six generating companies and a transmission company that have all been fully taken over and commenced operations (see Appendix 1 for the complete list). Second, a cost-reflective tariff (multi-year tariff order or MYTO) that would make the sector attractive to both local and foreign investors has reached a very advanced stage of implementation, albeit fraught with some challenges that are discussed later in this paper. Third, there is emergence of several independent 
power plants with combined capacity to generate an additional 2,500 MW of electricity. Fourth, regulatory institutions responsible for implementing the proposed reforms have been established. Fifth, significant efforts are ongoing to improve the gas-to-power infrastructure which is the greatest constraint on electricity supply in the country and results from pipeline vandalism and gas pricing policy. Lastly, several policies and market rules are being developed to guide the emerging privatized power sector at different stages of the reform that include a pretransition stage, a transitional stage, and a medium-term stage.

Figure 1: Duration of electrical outages and impact on business sales in Nigeria and comparator countries

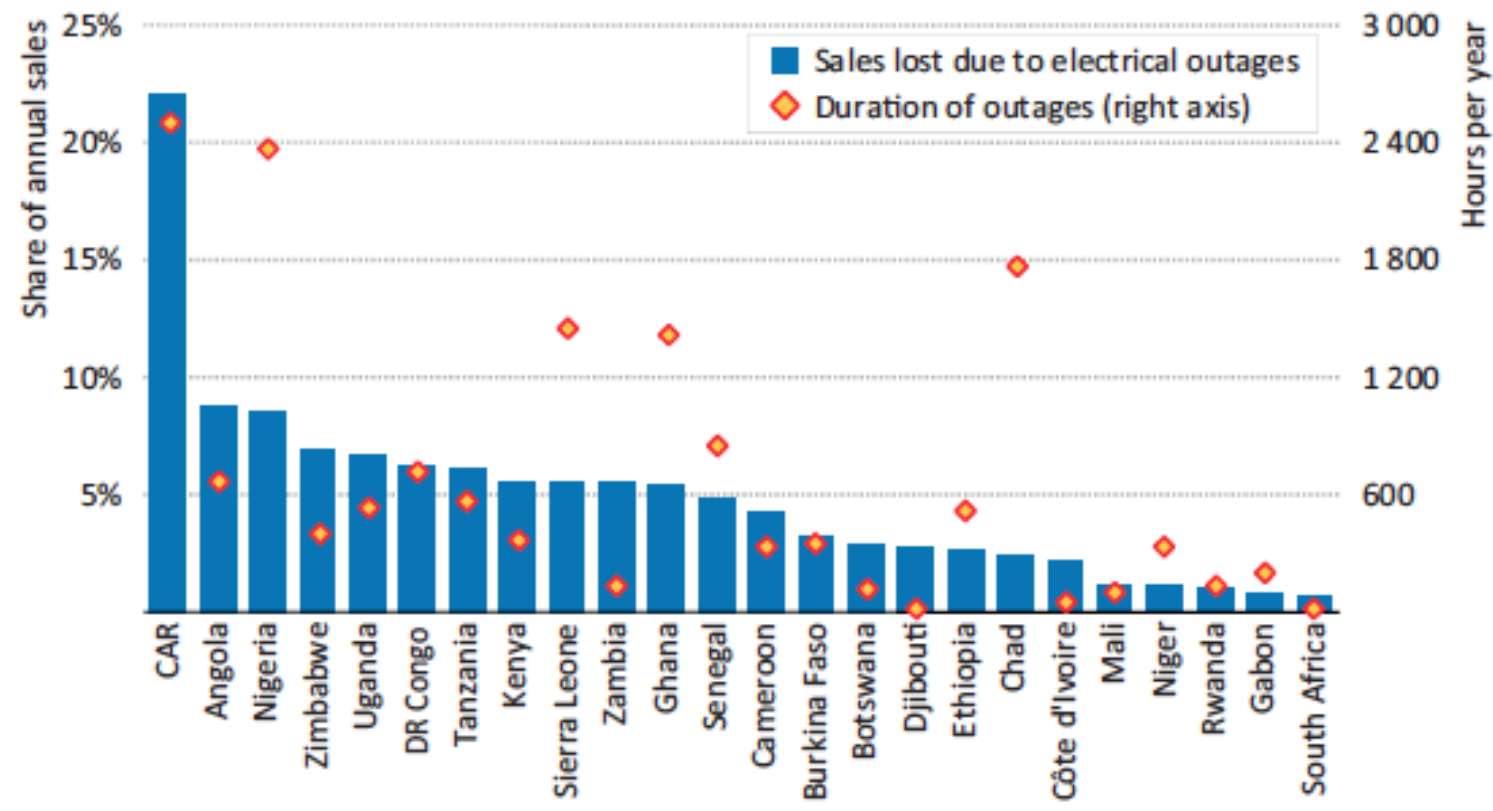

Source: IEA (2014: 26).

Despite the progress, challenges remain. These include: raising long-term finance for the emerging generation and distribution companies with estimated required annual investment of US \$7.5 billion between 2014 and 2020; sourcing the required manpower with the requisite skills for the emerging privately owned distribution and generation companies; creating an effective gas pricing system and tackling insufficient gas supplies to some power plants across the country; and staying the course of the reform given the challenging political and macroeconomic environment.

The most prominent of these is the political environment surrounding the reform, mainly regulatory and institutional issues. First, it can be argued that the long-lasting monopoly of the sector by government exacerbated by over-regulation was the dominant factor behind the deterioration in the country's energy sector over the years, culminating in its current deplorable state. Second, sustainability of the reform is at risk given the current weak institutional and regulatory framework driving the process. Third, the reform is generating emerging challenges that require development of an effective post-reform strategy on regulatory, institutional, and human capacity issues. Fourth, the state of insecurity in the country, especially in the Niger Delta region, induces incessant gas pipeline vandalism. This has serious implications for the progress of the reform as gas supply to the power stations is being constrained. Fifth, a cost recovery challenge has emerged recently. This is an outcome of the alleged over-priced power plants and 
distribution companies during the bidding process by the eventual buyers. ${ }^{1}$ Sixth, the MYTOs have also been a thorny issue, with incessant complaints by industrialists while residential consumers engage in sporadic demonstrations and protests over energy bills that do not match supply availability and quality of service. Seventh, weak political will to invest in the sector, now exacerbated by the country's current challenging fiscal revenue position. This is a major concern because transmission would remain under government ownership, though managed by an independent private firm. Eight, there is need for increased investment in clean energy to achieve optimal mix of energy sources with emphasis on hydro and solar power sources. This appears not to be high up the agenda meanwhile. Lastly, there is need for continued development of enabling laws and regulations that would ensure compliance enforcement in the sector.

A few studies have attempted to assess the energy sector reform in Nigeria (see Adenikinju 2003; Idris et al. 2013; Joseph 2014; Oke 2008; Okoro and Chikuni 2007; Sanyaolu 2008; Tallapragada and Adebusuyi 2008). Some have focused on the investment opportunities and pitfalls offered by the reform (David-West 2014; Onochie et al. 2015). Others have assessed the impact of the reform (Adoghe et al. 2009; Okafor 2008). Yet others have looked at it from consumer perspective (Ochugudu and Onodugo 2013). Generally, most of these studies have focused mainly on the challenges and opportunities offered by the reform without paying particular attention to the political economy of the reform process. Indeed, none provide a detailed, comprehensive, and historical assessment of the reform in the context of the institutional, regulatory, and legislative contexts. Hence, there is a need for a study that provides a holistic approach to assessing the reform in the context of the legislative, administrative, institutional, and financial issues surrounding the reform. Also, an evaluation of the emerging political economy associated with the reform process is imperative.

Following this introduction, Section 2 provides a brief history of the power sector reform. Section 3 articulates the key policies driving the reform, while Section 4 is preoccupied with the processes. Section 5 examines the targets and achievements of the reform, while Section 6 peruses the thorny electricity tariff issue. Section 7 outlines the key challenges threatening the reform. An assessment of the reform is the focus of Section 8, with Section 9 focusing on the political economy of clean and renewable energy in the country, and Section 10 concludes with a way forward.

\section{Brief history of the power sector reform}

Prior to the power sector reform, Nigeria operated a bundled power sector system. Government involvement in the power sector dates back to 1896, when the first-ever diesel firing plant in Nigeria, with capacity to produce 20 MW of electricity, was installed in Ijora, Lagos, followed by other small-scale diesel-powered plants in several other locations. In 1951, the Electricity Corporation of Nigeria was established to serve as a national agency charged with the responsibility of supervising and coordinating electricity distribution in the country through the use of captive or embedded generators. A major breakthrough was made in 1956 with development of a $30 \mathrm{MW}$ coal-fired plant in Oji River, in the south-eastern part of the country.

\footnotetext{
${ }^{1}$ Some generation and distribution companies have claimed that the power assets purchased during the privatization process were overvalued because the data and information provided to them by the government was wrong and inflated. Examples of such alleged wrong data include the customer base and aggregate technical, commercial, and collection loss level.
} 
Shortly after, in 1961, the Niger Dams Authority was established to assist in meeting the increasing demand for electricity in the country. In addition, the agency had the responsibility of exploring, building, and managing hydroelectric dams and other sources of power generation (gas, oil, and coal) in the country. Furthermore, it was authorized to build, maintain, and operate the country's transmission grid. The Niger Dams Authority succeeded in raising the country's power generation to 3,000 MW with equivalent transmission grid between 1961 and 1972 (see Table 1 for historical power generation over recent years). A far-reaching decision was taken in 1972 to bundle the Electricity Corporation of Nigeria and Niger Dams Authority into an agency known as NEPA, resulting in a vertically integrated power sector monopoly. This brought all power sector value chain activities involving generation, transmission, distribution, and marketing under the purview of this single entity. The strategic importance of the sector, economies of scale, and effective coordination and standardization were some of the rationales for the bundling policy.

Table: Installed electricity generation capacity (MW)

\begin{tabular}{llll}
\hline Year & Thermal & Hydro & Total \\
2007 & $6,021.50$ & $1,938.40$ & $7,959.90$ \\
2008 & $6,531.10$ & $1,938.40$ & $8,469.50$ \\
2009 & $6,763.90$ & $1,930.00$ & $8,693.85$ \\
2010 & $6,487.00$ & $1,930.00$ & $8,417.00$ \\
2011 & $6,972.00$ & $1,930.00$ & $8,902.00$ \\
\hline
\end{tabular}

Source: FMoP (2012).

Recent power sector reform in Nigeria is traceable to September 1990, when partial commercialization of the then NEPA was undertaken. The first step in this direction was the appointment of a managing director/chief executive officer to oversee the affairs of the institution. The second step involved dividing the institution into four autonomous divisions headed by an executive director, namely, Generation and Transmission; Distribution and Sales; Engineering; and Finance and Administration.

A further policy push was accorded the reform with the development of the National Electric Power Policy in 2001. This policy was the fallout from the study commissioned by the federal government in 1999 aimed at understanding the challenges of the power sector and proffering policy to transform the sector. It set the following as its key objectives: provide the framework for attracting private sector local and foreign investment into the sector; heighten local capacity in power sector technology; develop an effective and transparent regulatory framework to guide the power sector; promote full liberalization of the electricity market through promotion of competitive sector engagements that will help meet the growing electricity demand; ensure divestment of government investment in power sector entities and enshrine principles of restructuring; and review, with a view to updating the power sector laws that will help promote competition and private sector operations. This policy set the tone for the reform agenda and was, indeed, the birth of the modern-day power sector reform in Nigeria.

The reform was given great momentum in 2005 with the enactment of the Electric Power Sector Reform Act (EPSRA). The EPSRA was initiated to provide the legal backing for the reform and deliver the following objectives: (1) provide for the formation of holding company and successive privately owned companies to take over the functions, assets, liabilities, and staff of NEPA; (2) develop competitive electricity markets; (3) establish the power sector regulatory agency to be known as the Nigerian Electricity Regulatory Commission (NERC); (4) prescribe 
the procedure for licences and tariffs for power generation, transmission, distribution, system operation, and electricity trading; (5) prescribe the procedure for consumer protection and licensee performance and enforcement of these obligations; (6) stipulate the process for competition and market power; and (7) provide for the Power Consumer Assistance Fund and Rural Electrification Fund. The ultimate goal of the reform is to increase efficiency, accessibility, reliability, and affordability of quality electricity supply, with a view to stimulating economic growth, development, and transformation in the country.

To strengthen and provide momentum for the power sector reform enshrined in the Act, a Roadmap for Power Sector Reform was developed in 2010, with its latest revision in 2013. The 2010 Roadmap outlines the country's plan to accelerate the reforms specified in the EPSRA with a view to achieving the indicated short-term targets. It serves to guide the progress towards the final and supposedly most important stage of the reform process, namely, privatization, ownership, control, regulation, and operationalization of the power sector projects.

Prior to the Roadmap, President Goodluck Jonathan established the Presidential Action Committee on Power (PACP) in June 2010 to drive the implementation of the reform process by eliminating red tape and unnecessary bureaucracy associated with government decisions involving the power sector reform. The unique thing about the PACP is that it brings together, for the purpose of collaboration, all key agencies and institutions that have a significant real and potential role to play in removing regulatory and legal challenges facing private sector involvement in power sector development and operations.

The PACP is also tasked with responsibility for monitoring the conceptualization, planning, and execution of short-term power generation, transmission, distribution, and fuel-to-power projects that would help expedite the speed at which the country would met the targets set in the EPSRA and subsequently the Roadmap. The Presidential Task Force on Power serves as the executive arm of the PACP and is responsible for monitoring implementation of the Roadmap for Power Sector Reform. Also, a renowned professor of Computer Integrated Manufacturing and Robotics, Professor Barth Nnaji, was appointed as Special Adviser to the President on Power, and later became the Minister of Power. These bodies provided complementary roles for driving the reform process.

Following the processes outlined in the EPSRA, the first action was to establish an initial holding company-the PHCN-for the state-owned monopoly power company NEPA, and subsequently unbundling it. This action led to emergence of 18 successor companies, namely 11 distribution companies, ${ }^{2}$ six generation companies ${ }^{3}$ and one transmission company (Transmission Company of Nigeria). ${ }^{4}$ These six electricity generation companies and other independent power producers were structured to sell the electricity produced to the distribution companies, with each having jurisdiction over a pre-defined geographical area. While the generation and distribution segment of the power sector are completely privatized, the ownership of the transmission process is retained by the federal government but contracted to be managed on behalf of the government by Manitoba Hydro International (MHI). All the privatized successor companies were handed over on 1 November 2013.

\footnotetext{
2 Abuja, Benin, Eko, Enugu, Ibadan, Ikeja, Jos, Kaduna, Kano, Port Harcourt, and Yola. Each distribution company has exclusive control over the supply of electricity within a designated geographical area.

${ }^{3}$ Afam, Egbin, Kainji, Sapele, Shiroro, and Ughelli.

4 This is purely an electricity dispatch company responsible for transporting electricity from the point of generation to the point of distribution.
} 
MHI emerged as the sole firm to meet the benchmark for the bidding process, following the withdrawal of EBS International of Ireland and the inability of Power Grid Corporation of India to meet the technical benchmark. The MHI contract that commenced in July 2012 had a total contract sum of US $\$ 23.7$ million for three years, ending in July 2015, with an option for two years' extension. In the contract, Transmission Company of Nigeria (TCN), under MHI, is assigned the role of reducing electricity losses during transmission; ensuring improved security of the grid system and its seamless stabilization; improving general performance and reorientation of the management culture of the Nigerian staff of the TCN. For each of the TCN staff, a Nigerian counterpart was appointed as deputy or in other management positions to learn from the TCN management staff. TCN was obliged to transfer to the Nigerian counterparts the needed skills over the contract period. It was thought that contracting management of the TCN to MHI would help the TCN evolve into a stable, financially sustainable, self-sufficient and market-driven power generation company.

Overall, the objective of retaining the transmission arm of the electricity value chain in the hands of the government and handing its management over to $\mathrm{MHI}$ is to ensure that this segment of the industry is managed to become a technically and financially viable entity through developing local expertise that would be sufficiently technically empowered to take over management of the transmission processes in the industry.

\section{$3 \quad$ Key policies driving the power sector reform}

Several policy initiatives, pronouncements, and documents have been produced by the government to serve as guidance in the power sector reform process (see Appendix 2). While some are overarching in nature, cutting across the entire spectrum of power, others are subsector and activity-specific. Its is instructive to note that some of these policy pronouncements, good as they sound, never go beyond the level of pronouncements; many were merely produced and never implemented. An example of such policies is the promotion of renewable energy and energy efficiency. While several drafts have been developed over the years, they have remained as drafts with none of them reaching the level of implementation. It is hoped that the newly approved 2015 National Renewable Energy and Energy Efficiency Policy (NREEEP) will get past this hurdle.

One key observation about the power sector reform-related policies is that they are very numerous and appear uncoordinated, as many of them are not in sync nor do they 'talk' to each other. They are also characterized by obvious overlaps and conflicts. An example of such overlaps and conflicts is discernible among the National Power Training Institute of Nigeria (NAPTIN), Standards Organization of Nigeria and National Environmental Standards and Regulations Enforcement Agency in the monitoring of and enforcing compliance with the technical and operating standards in the power sector. Ambiguity is also rampant in some of the policy documents, with generic, broad, and unclear objectives lacking specificity. This reflects the lack of agreement among politicians, policy makers, and key power sector stakeholders. For example, the 2007 National Energy Master Plan (NEMP) was overly ambitious. Assuming an annual GDP growth rate of 10 per cent and using this to set energy generation targets at 15,920 MW, 30,210 MW, and 192,000 MW for the short-, medium-, and long-term, respectively is, to say the least, tantamount to a young child dreaming of riding on a butterfly. Of course, there is nothing wrong in dreaming and dreaming big. What is wrong, though, is just churning out figures without ensuring the supporting environment, infrastructure, finance, and commitment are available to actualize the dream. 
Little wonder, therefore, that these targets were significantly reduced in the 2008 Electricity Master Plan (EMP) to 6,000 MW, 10,000 MW, and 50,000 MW, for short-, medium-, and longterm, respectively. Even then, the 2008 EMP is still significantly out of tune with the 2010 Roadmap. While the 2008 EMP proposed a generation target of 7,365 MW in 18 months, the Roadmap proposed 7,000 MW by the end of 2011. Also, the 2008 EMP target of 10,000 MW by the end of 2013 is not in accord with the 14,000 MW target of the Roadmap.

The NREEEP is the newest entrant into the power sector policy pool. Approved by the Federal Executive Council in April 2015, the policy sets out to achieve some key deliverables geared towards the ultimate goal of achieving sustainable inclusive development through optimal utilization of Nigeria's energy resources. Based on recognition of the multi-dimensional nature of energy, the policy aims to address diverse issues relating to renewable energy: planning and policy implementation; legislation; research, and development; regulation and standards; supply and utilization; financing and pricing; capacity-building and training; efficiency and conservation; project implementation; gender; and environmental issues. It is still too early to assess this policy because the implementation strategy is still being worked out.

\section{$4 \quad$ Processes of the power sector reform}

The power sector reform was planned in phases. Five major activities were scheduled to be undertaken under the first phase of the reform process. First is the unbundling and privatization of the long-lasting government-owned monopoly power company (NEPA) that has overseen the affairs of the power sector for so long. This resulted in the creation of the initial holding company (the PHCN) as stipulated in the EPSRA. The firm was structured to exist alongside the independent power producers with signed agreements to buy the power they generate. The second activity involves creation of an independent power sector regulator (NERC) to ensure sanity in the market and carry out other standard regulatory functions that include consumer protection and global welfare maximization through effective regulation that will attract private domestic and foreign investors to the sector.

Third was incorporation of the PHCN successor generation and distribution companies so that they could take over both the assets and liabilities of the parent company. The fourth activity was creation of a multi-purpose entity that would have the function of procuring electricity from the independent power producers and newly created generation companies for subsequent sale to the distribution companies. This gave birth to NBET, a special-purpose public liability company established to undertake electricity power trading and management of existing liabilities among power firms. The final activity was establishment of the training institute, NAPTIN. The purpose of this institution was to bridge the observed human capital deficiency in the power sector through effective training of power sector personnel. It also aimed to coordinate training activities in the sector, thus making sure the successor privatized firms have a wide array of efficient and well-trained staff across the spectrum of the country's power sector value chain.

The second phase, which has a medium-term horizon, involves developing a cost-reflective electricity tariff to ensure competitive pricing that would attract private sector participation in the privatization process. The ultimate aim is to make investment in the sector attractive enough and sustainable for all prospective investors. During this phase, the privatization process was expected to have been completed, implying that all the successor power companies would have been up and running. The completion of the privatization process implies that electricity market competition would have been enshrined to a limited extent with the successor companies initiating bilateral energy transaction agreements among themselves and the independent power producers. 
The third phase, which is the final long-term phase, focuses on achieving a completely competitive power sector. In this phase, a full cost-reflective power sector is anticipated. One of the key activities during this phase includes selling the 80 per cent government stake in the ten gas-fired power plants ${ }^{5}$ jointly owned by the three tiers of government under the management of the Delta PHCN.

\section{Targets and achievements of the power sector reform}

Analysis of the achievements of the power sector reform is best undertaken by outlining the key goals of the reform. These goals can be broadly categorized into: (1) defining a new national power policy that positioned the private sector as driver of the sector on funding, innovation, and leadership; (2) designing an enabling regulatory, policy, and commercial framework for engagements of all stakeholders in the sector; and (3) commercialization of the sector. In more specific terms, the Roadmap for Power Sector Reform outlines specific tasks to include: establishment of a bulk purchaser/trader; strengthening the NERC; provision of Federal Government Credit Enhancement; operationalizing the Nigerian Electricity Liability Management Company (NELMCO); strengthening the training institute, NAPTIN; strengthening technical and managerial capacity of the TCN; and sale of Nigeria's generating companies and distribution companies to the private sector.

The goal of ensuring development of a national policy on power has been largely achieved. The country now has a sufficiently robust policy on power to guide activities in the sector. However, there is nothing really new about the policy because several bits and pieces of it have been in existence since long before commencement of the reform initiative. More recently, in April 2015, the NREEEP was approved by the Federal Executive Council as an additional policy guide for the sector. Again, this is not entirely new because earlier renewable policy documents existed before this (see, for example, the 2005 Renewable Energy Master Plan and the National Energy Policy on Renewable Energy). It is noteworthy that the number of policy guides and documents in the sector appears overwhelming and needs to be consolidated into much smaller number for effective implementation, monitoring, and evaluation.

The reform targeted privatization of the sector. This aimed to change the long-standing framework where state-owned NEPA, and later PHCN, was solely responsible for electricity generation, distribution, and transmission in the entire country. To achieve this, one target was that activities of this state-owned enterprise be unbundled into generation, distribution, and transmission. The target of setting up a holding company within six months of the EPSRA coming into effect, as contained in the Act, was achieved. While the Act came into effect on 11 March 2005, the Bureau of Public Enterprises created a holding company out of NEPA by rebranding the institution and naming it as the holding company, a precursor to the full privatization of the power sector.

The privatization has now been concluded with the completion of the handover of all 17 distribution and generation companies that emerged from the privatization process in November 2013. This followed receipt of around US $\$ 2.5$ billion, which represents the total value of the sale price for the privatized assets. For the generation activities, the thermal power stations have been successfully sold while the hydropower stations have been concessioned. The management of the only transmission company that remains under control of the government was also handed

\footnotetext{
${ }^{5}$ Olorunsogo (750 MW); Calabar (561 MW); Alaoji (450 MW); Ihovbor (450 MW); Omotoso (450 MW); Sapele (450 MW); Geregu (434 MW); Egbema (338 MW); Gbarain (225 MW); and Omoku (225 MW).
} 
over to a privately owned management company with the long-term objective of privatizing this activity or managing it through a public-private partnership. Also, in total, no less than 70 independent power producers have been licensed to generate power, thus confirming significant progress in privatization of the sector. However, the power sector policies have not sufficiently succeeded in positioning the private sector as the driver of the power sector on funding, innovation, and leadership. The lack of an independent industry regulator, a cost-reflective pricing system, and firm contracts with open access to the power network, are among the factors that may be responsible for this outcome. The sector still experiences the irony of increased government funding while privatization of the sector is being undertaken.

Another important target of the reform was the establishment of the legal and institutional framework for effective delivery of the reform. The EPSRA specified establishment of the following institutions and participants: the Federal Ministry of Power; a regulatory commission (NERC); generation companies; the transmission company (TCN); a Special Purpose Entity; ongrid distribution companies; off-grid distribution companies; and grid-connected autogenerators. Most of these targets have been met. NERC has been created as an industry regulator responsible for playing the role of a facilitator and enabler of activities in the sector through effective regulation and oversight of all stakeholders in the sector.

Another important institution is a bulk trader that would 'engage in the purchase and resale of electric power and ancillary services from independent power producers and from the successor generation companies' until such time as the market is fully privatized and sufficiently mature to play this role through the forces of demand and supply (EPSRA section 25a). Initially, this role was assigned to NELMCO that was created to carry out roles including taking over NEPA's energy purchasing obligations, signing subsequent power purchase agreements (PPAs), selling power to the distribution companies, taking over the non-core assets of PHCN, and financing its inherited legacy debts and stranded liabilities. However, with establishment of NBET, the role of purchasing power agreements was excluded from NELMCO's core activities and given to NBET. The Operator of the Nigerian Electricity Market has also been created to act as wholesale market and settlement operator responsible for managing the metering system among generation, transmission, and distribution companies. Indeed, there appears to be multiplicity of institutions in the reform process, thus increasing the risks of overlapping functions among them.

Another landmark achievement in the institutional framework of the power sector reform was the establishment of the Rural Electrification Agency to promote, support, and provide access to electricity in rural and semi-urban areas of the country as well as administer the Rural Electrification Fund. The Gas Aggregation Company Nigeria Ltd has also been established to stimulate growth of natural gas utilization in the domestic market, especially the power sector. Also the national training institute, NAPTIN, has been established, to serve as a a focal point for human resource development and workforce capacity-building for power activities in the power sector value chain.

The electricity commercialization target is yet to be fully met, though. One of the key challenges to meeting this target is the less than optimal illiquidity of the electricity market. Hence, an Interim Rule period was established as a precursor to a stage when all electricity market transactions will be market-based, otherwise known as the Transitional Electricity Market (TEM). The TEM arrangement that came to effect on 1 February 2015 is the first private power market in Africa that allows allocation of limited revenues to relevant stakeholders in the electricity market, beginning from the period when successor companies were handed over to the buyers. Another challenge limiting achievement of the commercialization target is the institutionalization of the cost-reflective system. 
On 1 June 2012, a cost-reflective tariff, MYTO 2, aiming to make the sector attractive to both local and foreign investors, was finalized by NERC. However, the country appears to be stuck at that point as no significant progress has been made in advancing to a tariff system that addresses a cross-subsidy for poor households. The electricity tariff structure is yet to achieve the costreflective framework desired, thus limiting electricity commercialization. A reviewed tariff is expected to take effect on 1 February 2016. This is being introduced as a solution to the financial incapacitation of the generation, distribution, and transmission companies resulting from insufficient earnings that have hindered investment in power infrastructure.

Nigeria now has about 23 operational grid-connected generating plants, with total installed capacity of around 10,396 MW and available generation capacity of about 6,056 MW. Added to this is establishment of the National Integrated Power Project (NIPP) in 2004 for the purpose of fast-tracking power initiatives funded by the public sector. There are currently no less than 10 new NIPP plants that have a total combined capacity to generate 5,455 MW. In August 2015, an unprecedented peak generation level of 4,810 MW was reached.

The targets of 40,000 MW for total power generation and 8,188 MW for renewables by 2020 are, to say the least, not just overly ambitious but impractical and completely unattainable. Of course, demand still far outstrips supply (Figure 2). Another overly ambitious and unmet target is the 75 per cent rural electrification target. This has been a recurring ambition in all the energy policy documents relating to rural electrification. Yet this will remain elusive over the medium term given the state of the power sector, which has been on lower ebb since the change in government in May 2015.

Figure 2: Historical maximum demand and generated energy in Nigeria

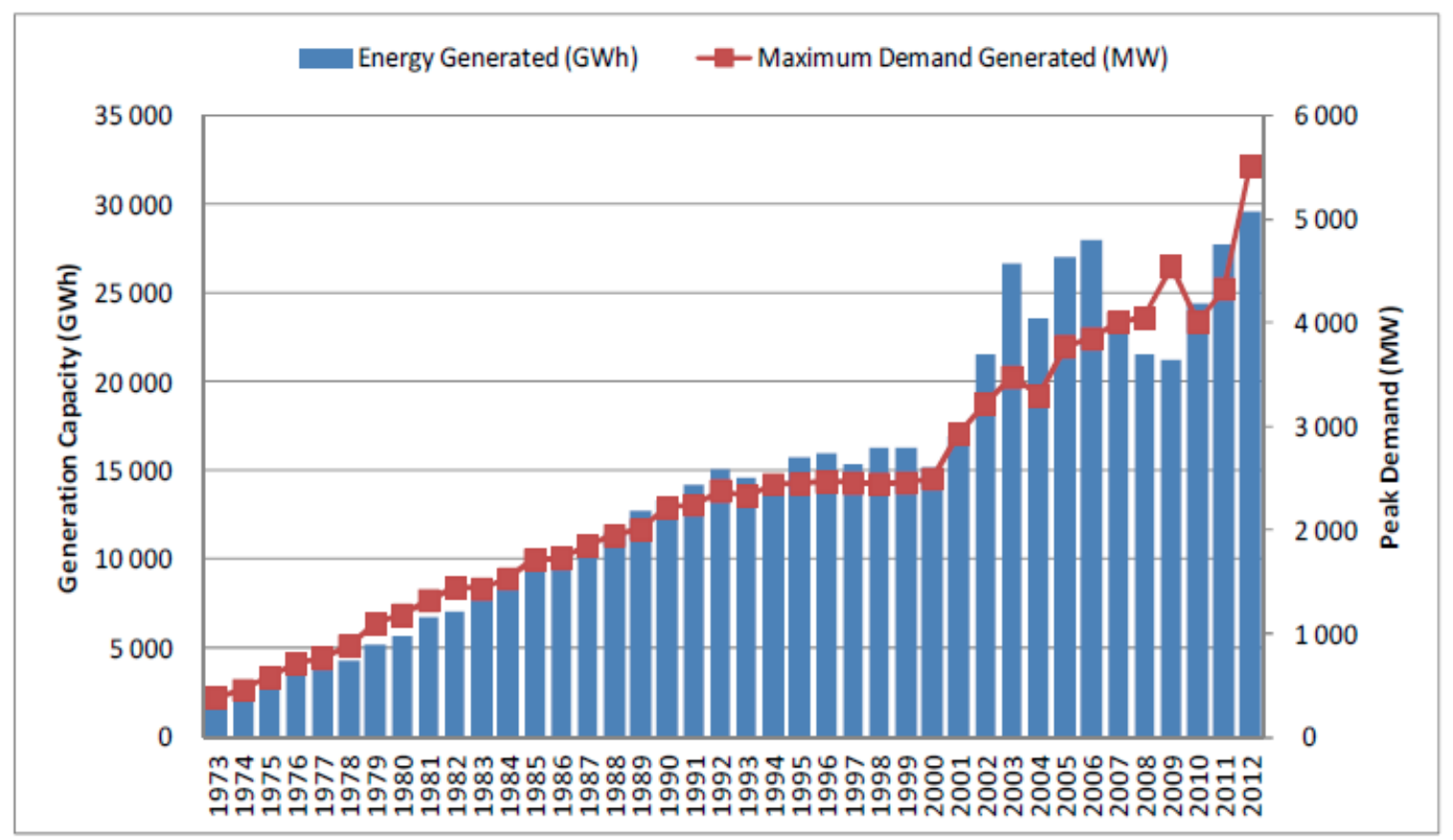

Source: TCN (2012: 24).

\section{$6 \quad$ Electricity tariff}

Another key political economy issue in the power sector reform, and the extent to which it balances the interests of investors with those of consumers, is electricity pricing. Indeed, for this type of reform to be politically and socially acceptable, there is a need to ensure that the poorer 
members of society are not made worse off. However, this has been a major issue in recent times with regard to the existing tariff structure in the power sector. The target of the power sector reform is to achieve a cost-reflective electricity tariff over a reasonably short period of time. For a long time, the absence of a cost-reflective electricity tariff has been one of the main deterrents to local and foreign investor participation. To correct this anomaly, the power sector reform target is to introduce a cost-reflective tariff through the MYTO, which allows a minor review every six months and a major review annually. In this framework, consumers are categorized into residential, commercial, industrial, special, and street lighting. The purpose of this tariff structure is designed to achieve four simultaneous objectives: to ensure fairness to consumers; to allow licensees to recover all reasonable costs within a reasonable period of time; to provide sufficient funding to finance activities of investors; and to allow for reasonable earnings to achieve efficient operations.

The first set of cost-reflective tariffs, otherwise known as MYTO 1, was successfully rolled out in 2008 covering the period between July of that year to 30 June 2013. However, a new tariff, MYTO 2-a 15-year tariff path for the industry-was introduced in June 2012 with minor revision in June 2013. The broad customer classification is the same as MYTO 1. Following wide public and stakeholder consultation, MYTO 2.1 was amended on 1 April 2015, resulting in varying tariff rates for each distribution company. The review aims to reflect the current market conditions, with cost of supplying electricity to the wide range of consumers, inflation rates, exchange rates, gas supply price, generation capacity, capital expenditure, operations expenditure, and cost recovery and reasonable return on investment for investors as guiding posts. The aim of MYTO 2 is to provide more stability over 15 years for the electricity industry, with minor annual reviews and a major review every five years until the market becomes fully competitive. The country still has not achieved a tariff that is cost-reflective and commercially viable and sustainable.

However, challenges exist with implementation of the cost-reflective tariff. For instance, just one year after the initial roll-out, NERC found two major deficiencies in the new price structure. First, it was realized in 2009 that there had been a substantial shift in the two key variables used to determine the tariff, namely, gas prices and exchange rates. What this implies is that with these changes, the supposedly cost-reflective tariff remained too unattractive to draw in investors. Second, the tariff only made provisions for gas as a source of power generation, leaving out other sources such as wind, coal, and solar power. Yet some investors were willing to explore these sources in their power generation investment bid. This necessitated a review of the tariff by NERC earlier than scheduled.

The review and ensuing new tariff rates that are expected to take effect on 1 February 2016, contain some key amendments. First, the new tariff takes account of technical or commercial losses in the electricity generation, transmission, and distribution chain. Specifically, and in the spirit of fairness, collection losses defined as 'amount billed but not collected', which is within the control of the distribution companies, are not allowed to be passed on by them to the consumers as had been done previously. Only verified technical and commercial losses are allowed to be passed through to consumers. Second, the MYTO 2 financial model is adjusted to include the level of the aggregate technical, commercial, and collection losses for each distribution company with zero collection loss. Rather than the past financial model, where aggregate technical, commercial, and collection losses were generalized across all generation companies, such losses are now to each generation company and treated separately. Updated data and information on current inflation rates, exchange rates, gas price, energy imbalance, and generation capacity are used in the review. 
One interesting feature in this tariff review is the consideration of fairness and public interest as key factors. The fixed charge that was an intrinsic part of the earlier tariff system has now been removed for vulnerable customers and those operating in the informal sector. It is, indeed, unfair and imprudent to allow distribution companies to make the customers pay for their own inefficiencies involving an inability to collect what is due to them from customers that have used the service. However, the caveat that any distribution company 'that wishes to pass through certain collection losses to consumers shall be required to apply to the commission, in accordance with the provisions of the Regulations on Procedure for Electricity Tariff Reviews, and justify with evidence the portion of the losses to be passed through to consumers' (NERC 2015: 7) is open to abuse. Also, open to abuse, with the possibility of becoming a slippery slope, is the provision that verified technical and commercial losses can be passed through to consumers. There is ongoing public discontent about the expected higher tariff when the new tariff becomes effective. This emanates from the belief that the service has not improved enough to warrant payment of higher tariffs.

\section{$7 \quad$ Key challenges facing the power sector reform}

Poor transmission network. The transmission segment of the power sector is the weakest link in the entire electricity value chain. Transmission lines are notorious for being very old and weak. Some of the cables are compromised and can no longer withstand the pressures of carrying power lines. Worse still is the fact that the transmission lines are limited in scope and coverage of the country. Currently, the transmission lines are unable to successfully evacuate all the power generated to the point of need as total system collapse is a regular reoccurrence during peak generation period, thus increasing the level of trapped power generated.

What this means is that, even when there is additional capacity to increase power generation, this is constrained by limited transmission capacity that makes evacuating additional power load impossible. This could have serious financial implications for generation companies that do not share the blame but bear the consequences. One reason for the weak transmission lines is their limited capacity, being designed to carry between 3,000 and 3,500 MW. Another factor is the lack of regular maintenance of the transmission lines. Security challenges in some parts of the country, and in obtaining right of way for construction of new transmission lines, constrains expansion. Another factor is the bureaucratic system surrounding management of the TCN by MHI with government and political interference being the real issues.

Inadequate funding. Funding is one of the most acute challenges facing the power sector. Yet, substantial investments are required in the entire electricity supply chain. A rationale for the power sector reform is the need to reduce government funding of the sector through privatization that would leave financing of the sector mainly in the hands of the private sector. While up to 70 per cent of the loans and equity funds that paid for the assets came from the local financial market, the debt obligation on the firms is huge. Some of them are still struggling to pay back the huge debt. Worsening the situation are the large collection losses being declared by these firms, amounting to a substantial financial haemorrhage. To a great extent, the generation companies are responsible for the loss because they have not done sufficiently well to invest in strengthening the metering system that would discourage power theft and improve the collection rate. Excessive estimated bills that do not reflect power availability and consumption have also discouraged payments by consumers. The poor balance sheets of the banking system resulting from exposure to power sector loans appear to have weakened them and discouraged them from extending additional funding required for the reform. 
To tackle the financing challenges facing the reform, the government has taken the lead in proffering solutions through convening investor conferences, investment roadshows, and provision of special funding interventions to stakeholders in the electricity value chain, especially the generation, distribution, and transmission companies. For instance, on 2 August 2014, the government made available approximately US $\$ 1$ billion through the Nigerian Electricity Market Stabilization Fund. The purpose of this facility is to make funds available to power generation companies to settle legacy gas debts, address revenue shortfall during the Interim Rule period, and clear debts incurred through infrastructure upgrade, notably metering. In addition, the facility aims at guaranteeing the smooth take-off of the TEM. As of October 2015, about 30 per cent of this facility has been approved and disbursed to 18 participating firms. It is noteworthy, however, that such support usually tilts in favour of the distribution companies to the disadvantage of the generation companies. Earlier, NG $\$ 300$ billion was made available through the Power and Airline Intervention Fund.

It is noteworthy, however, that these intervention funds are temporary stopgap measure for addressing the funding challenge facing the electricity sector. A more permanent solution that assures sustainable private sector-led financing is the way forward. The World Bank and African Development Bank have initiated Partial Risk Guarantees for the power sector. But none of these is working because of the peculiar challenges facing the reform that are discussed in different parts of this paper. The investment requirement for the sector is huge and cannot be met by the government alone. One way to attract stable and sustainable private investment would be to enshrine a cost-reflective tariff. Also important is policy consistency that assures existing and prospective investors that the government is committed to the reform and will not reverse earlier policy commitments that would involve the loss of funds already invested.

Gas supply. Gas as a feedstock for power generation accounts for about 50 per cent of the total cost of producing power in Nigeria. This is significant considering that 80 per cent of total electricity generation in Nigeria comes from gas (Figure 3). Around 4.9 billion standard cubic feet (scf) of gas per annum is covered by the agreements between gas suppliers and electric companies, with just about a third of this being delivered. Yet, the country's installed power generation capacity would require gas supply of up to 7 billion scf per annum to adequately power them. Adequate gas supply to power generation is central to achieving the country's objective of electricity availability, affordability, and accessibility. Indeed, distribution companies have named insufficient gas supply as a major challenge constraining their finances because it limits the power supplied to them by the generation companies. 
Figure 3: Electricity production from different sources, percentage share

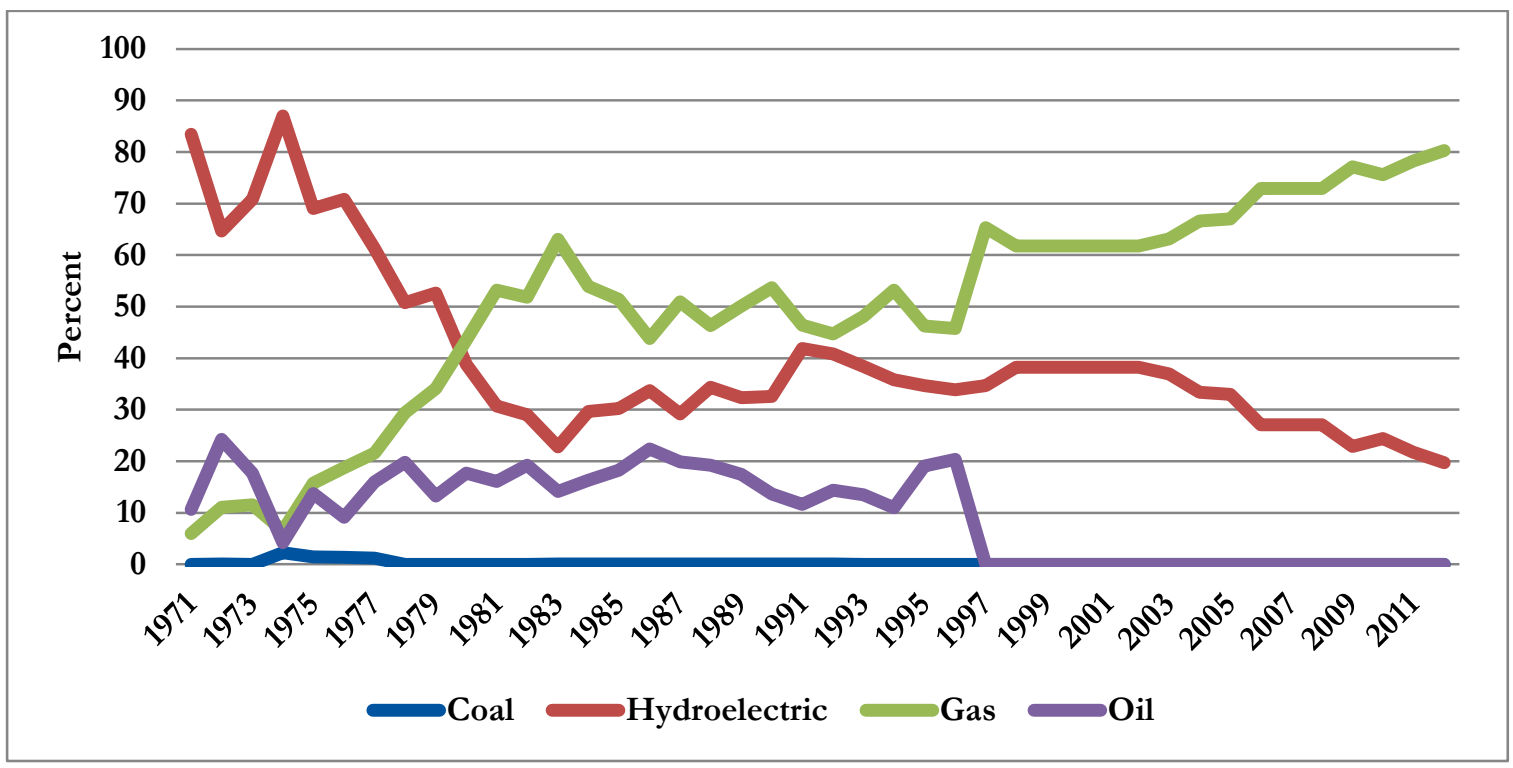

Source: Based on World Development Indicators database, accessed 15 June 2015.

Nigeria ranks among the top ten countries with highest proven gas reserves in the world (Figure 4), but rather than put this important resource to good use, a great percentage is wasted through flaring, leading to very low utilization rate (Figure 5).

Figure 4: Natural gas proven reserves in top ten countries, 2011-15

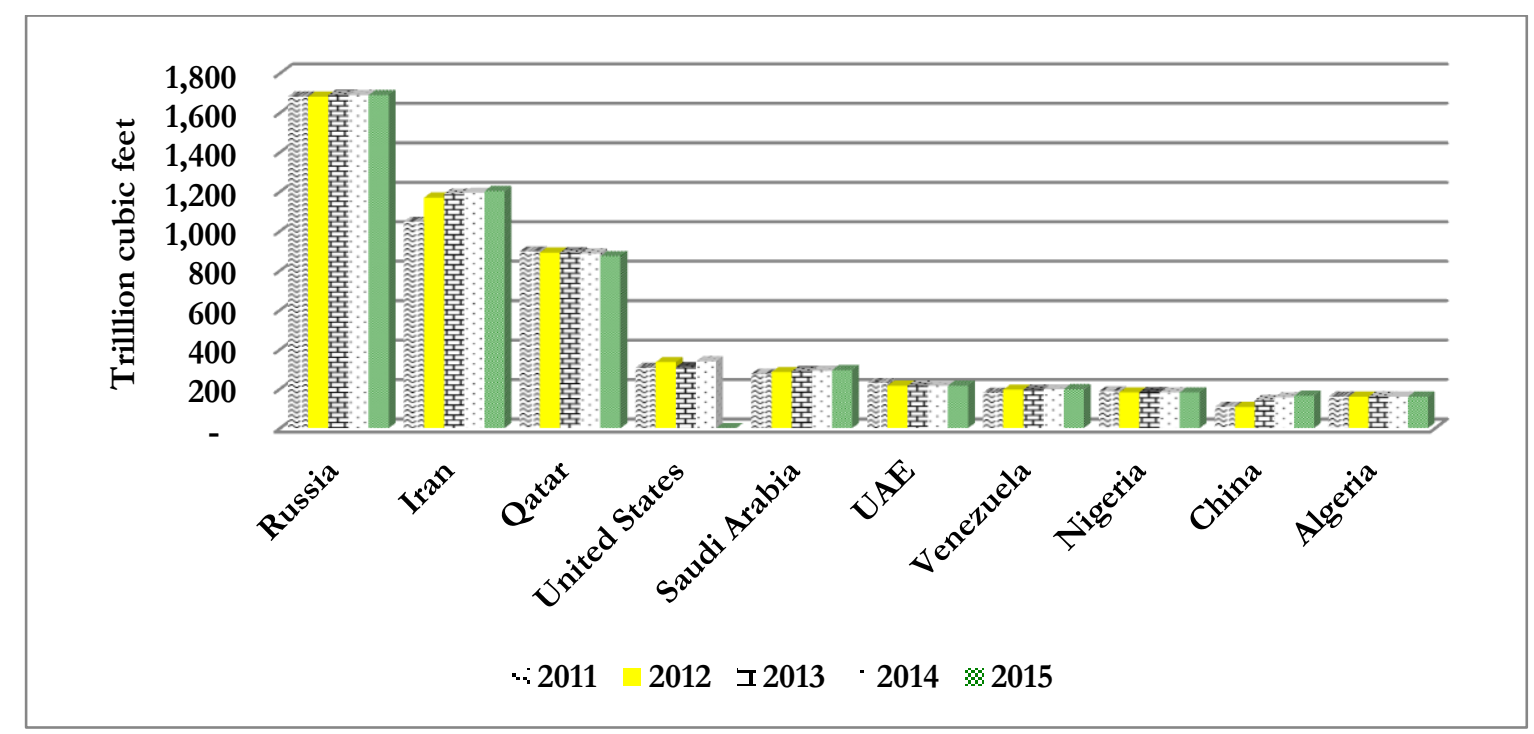

Source: Based on IEA database, accessed 22 July 2015.

Incoherent gas-to-power policy, low profitability of domestic gas supply vis-à-vis exports, and poor gas-to-power infrastructure are all challenges bedevilling the sector. The problem of gas to power can be broadly classified as gas pipelines vandalism and poor gas project facilities management (Amadi 2015). This boils down to the availability, affordability, deliverability, and commerciality of gas supply. 


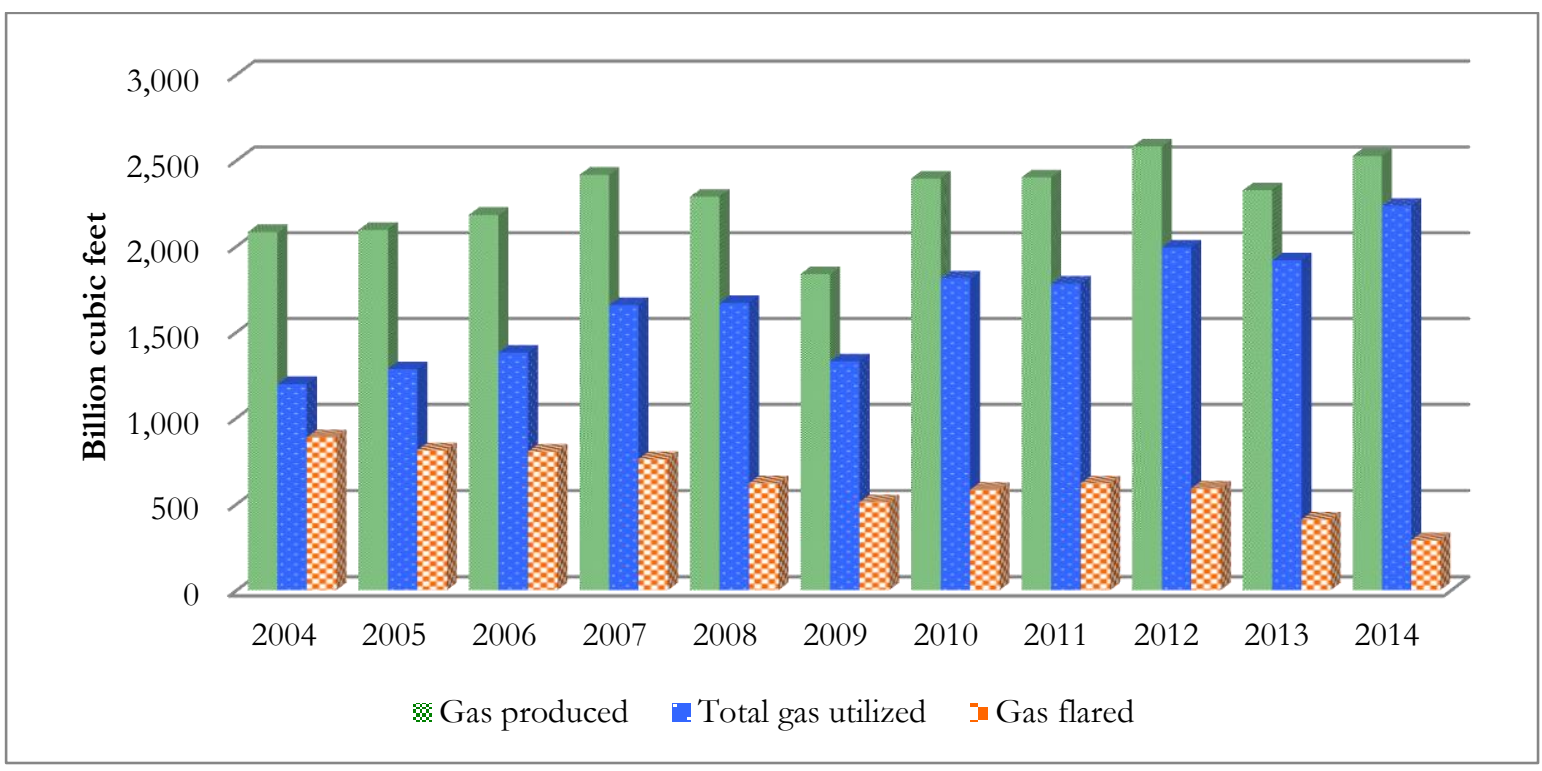

Source: PTFP (2015).

There is a significant gas supply mismatch with some completed power generation projects lacking gas supply while uncompleted projects have gas supply infrastructure available to them. For example, Geregu and Omotosho plants do not have gas supply infrastructure. Some of the key challenges constraining effective gas supply are political considerations around locating power stations, gas pipeline vandalism, long distances between sources of gas supply and power stations, and weak gas-to-power policy resulting in a misalignment between gas and power policies. The strategic importance of gas to the success of the power sector reform is demonstrated by the relative success of Transcorp Ughelli Power, a generation company in Nigeria that was able to increase its generation capacity from 160 MW to 453 MW within six months of operation owing to its power station's close proximity to gas supply locations.

Some political cum economic solutions have been proposed, and others are still being sought, to tackle the gas challenge. One is the development of the Gas Master Plan in 2008 to provide a guide for mainstreaming commercial exploitation and management of gas in the country through three key strategies: stimulating the multiplier effect of gas in the domestic economy; positioning Nigeria competitively in high-value export markets; and guaranteeing the country's long-term energy security. Second, efforts have been made by the government to allocate between 10 per cent and 15 per cent of the gas spot market supplied by Nigeria Liquefied Natural Gas to power generation companies. Third is establishment of the Gas Aggregation Company Nigeria Ltd with the aim of providing a framework for implementation of the gas master plan strategic framework for achieving a wholly competitive and market-driven domestic gas sector. Fourth is removal of an earlier government price cap on domestic gas supply. In August 2014, the government revised the gas-to-power price to US $\$ 2.50$ from US $\$ 2 / \mathrm{mcf}$ (per thousand cubic feet) and added US $\$ 0.80 / \mathrm{mcf}$ to cover transportation costs for new capacity. This and future guided policy on pricing are expected to bring the domestic price of gas closer to its international market price, thus encouraging domestic supply instead of exports. Fifth is setting up a special purpose financing facility to settle legacy gas supply debts. Lastly, the power sector regulator-NERChas made access to gas a compulsory condition for licensing independent power projects.

Limited human resource capacity, insecurity that challenged development of gas and transmission infrastructure, and the weak power wheeling capacity of the TCN are among myriad other challenges facing the reform. 
Cost-benefit analysis would have been the preferred methodology for this study. However, this would be impractical in view of the time and resources required to gather the necessary information and data for such analysis. Moreover, apart from the indicative investment of US $\$ 35$ billion over ten years for the sector-which is now grossly inadequate in view of current realities - not much data is available regarding the breakdown cost and quantifiable expected benefits of the reform. In the absence of this information, the study will be analytical and descriptive in nature.

Analysis of the policy documents relevant to the reform is undertaken vis-à-vis the projected and actual outcomes of the reform. Some of the documents analysed are: the EPSRA 2005; the Roadmap for Power Sector Reform; and progress reports by specialized agencies that include NERC, the Presidential Task Force on Power, the Ministry of Power, the National Rural Electrification Agency, Independent Power Plants, the Energy Commission of Nigeria, and so on. Since the study focuses on a contemporary issue, most of the information is sourced from real-life observations, speeches made by stakeholders involved in the reform, and presentations in different forums.

\subsection{Process infractions in the management of the privatization process}

From the outset, several allegations of infractions have surfaced in the power sector reform process. At the point of awarding the management contract of the TCN to MHI, both the then serving Minister of Power and the director-general of the agency responsible for the privatization process - the Bureau of Public Enterprises (BPE) — were relieved of their duties as a result of alleged infractions in the bidding process. The minister was found to have a conflict of interest as he had stakes in some of the firms bidding for some of the PHCN successor companies. Geometric Power, in which the minister had a stake, had joined Eastern Electric Nigeria Ltd and $\mathrm{O} \& \mathrm{M}$ Solutions of Pakistan in bidding for the Enugu Distribution Company and Afam Generation Company, respectively. Yet the minister maintained that he had no conflict of interest because he had informed the National Council on Privatization chaired by the VicePresident. He asserted that he had transferred his shares to a blind trust and did not participate in the day-to-day operations of the company.

Also, the director-general of the BPE at the time was believed to have been an accomplice in the non-disclosure of the conflict of interest of the minister in bidding for the privatized power entities since the BPE was the clearing house for the bids. In addition, the Senate ad hoc committee on privatization and commercialization had called for removal of the director-general on the grounds of alleged gross incompetence in the management of the privatization process, and alleged illegal and fraudulent sale of the federal government's 5 per cent residual shares in the Eleme Petrochemicals Company Ltd. In probing the privatization of government enterprises between 1999 and 2011, the committee said that the BPE director-general was also implicated in fraudulent disposal of the Aluminium Smelter Company to a Russian firm, Rusal, culminating in the Supreme Court invalidating the sale.

Granted, efforts were made to ensure a transparent and accountable reform process by sticking to the privatization guidelines throughout the privatization process. However, allegations abound of obvious obscurity, opaqueness, and favouritism in the selling process. One key instance of such was the sale of the Kaduna distribution company. The preferred bidder, Northwest Power Ltd (NPL), was unilaterally granted deadline extension for the completion of the Share Purchase Agreement rather than reverting to the reserved bidder as provided for in the privatization guidelines. This was an obvious act of favouritism because Section 15 (138) of the Request for 
Proposals for the Privatization of PHCN Successor Companies stipulated that failure of the preferred bidder to meet its payment obligation before the stipulated deadline would require that the 25 per cent down payment be forfeited while the right of purchase would be given to the reserve bidder. Specifically, Section 15 (140) stated that 'failure to complete the transaction within a mutually agreed timeframe will result in the forfeiture of the down payment as per the terms of the Share Sale Agreement.'

The position was that NPL paid 24 per cent of the total bid on 23 December 2013 and had until 23 June 2014 to settle the 75 per cent balance. When it became obvious that NPL was unable to meet the deadline, the BPE acted against the privatization rules by extending the payment date to 6 August 2014. NPL was unable to meet the 6 August deadline and therefore had to request a further extension to 6 October 2014. Again, this deadline was missed and further extended to 4 December 2014. Yet the BPE finally sold the entity to NPL, despite a court order secured by the reserve bidder to stop the sale. The claim by the BPE was that the National Council on Privatization (NCP) alone had the final say in the sale and had decided to use its discretion in the matter. In fact, in a letter to the Vice-President, who is the chairman of NCP, the BPE warned against handing over the asset to the reserve bidder, claiming that there was no guarantee that the reserve bidder would fare any better than the preferred bidder, and that doing so would set the process back by about 12 months.

\subsection{Political interference}

This is the most visible and challenging political economy issue facing the power sector reform in Nigeria. In contracting the management of TCN to MHI for US $\$ 23$ million for three years between July 2012 and July 2015, one of the key reasons proffered was the need to reduce the bureaucracy associated with public management of the enterprise with a view to improving efficiency of operations devoid of government interference. The firm was mandated to run the entire TCN system and turn it into a technically and financially efficient, sustainable, and stable company within the period of the contract. In addition, MHI was expected to ensure evolution of a TCN that would eventually become a private commercial company by reorganizing the institution so that the Transmission System Provider became a separate entity from the Market Operator and System Operator. In contrast to this thinking, however, management of the TCN appears to be fraught with serious political interference that tends to limit effective performance of the institution and dampen its ability to achieve the stated mandate.

At its inception, the process for awarding MHI the management of TCN was mired in controversies, leading to internal wrangling that bred operational lapses. For example, the chairman of the supervisory board of the institution has changed many times due to dissatisfaction and protests over political interference and alleged 'over-hyped' powers accorded the MHI. Some of the alleged powers include the hand over of the day-to-day running of the TCN and operations of its bank account to MHI, as well as allowing it to appoint a CEO without recourse to the supervisory board. One easy way of interference was in the expectation that MHI would contribute to developing local capacity that would eventually take over management of TCN through local counterparts that are expected to understudy the MHI expatriates. Change in the leadership of the MHI itself that is attributed to the internal wrangling has also been obvious within the short period of the contract.

There were also allegations that the provision for Nigerian counterparts to understudy the MHI expatriates was exploited by the political class to compensate loyalists and political jobbers. One obvious outcome of political interference in TCN activities is that it has made the institution the 
weakest link in the electricity reform value chain, with its non-performance rubbing off negatively on existing independent power producers, generation companies, and distribution companies, and ultimately on attracting much needed investment to the power sector.

Towards the end of the MHI contract in 2015, the transmission segment of the Nigerian power sector was enmeshed in and beclouded by uncertainty over who was in charge. At the twilight of President Jonathan's administration, the Minister of Power issued several last-minute directives that sometimes appeared contradictory. For example, there was an earlier directive that all actions with respect to the proposed unbundling of TCN be held in abeyance pending the decision of the incoming administration of President Buhari. However, ten days later there was another directive appointing a full management team to a supposedly unbundled TCN (now a System Operator and a Transmission System Provider).

Meanwhile, these new entities were yet to be incorporated as legal entities because their operating licences were yet to be issued by NERC and TCN had not been wound up. Also, proposing a change while the management contract of MHI still subsisted and might possibly be extended - it was ultimately extended by one year to July 2016-would only result in confusion and crises in the management of the entity, impinging on its overall performance. It is imperative to ask, however, what the basis was for the contract renewal. There are indications that there was neither careful nor clear assessment and evaluation of the contract terms of MHI vis-à-vis its performance on the agreed milestones that would inform the need to extend the contract or to act otherwise. It appears that the need to avoid a void in this segment of the power sector was the sole factor behind the renewal. The one-year extension should be sufficient to undertake the necessary evaluation of the situation that would result in a more permanent solution. Midway to the end of the contract extension, it remains doubtful whether there is any serious plan in place to strengthen the TCN management and it is difficult to ascertain what the future holds for this segment of the power sector.

\subsection{Corruption}

Corruption is one of the key reasons for the collapse of the Nigerian electricity sector and was, therefore, the main rationale adduced for its reform. Yet the reform has been embroiled in corruption allegations from the beginning. First, there were claims that the US\$16 billion invested in the NIPP under the President Olusegun Obasanjo administration was largely mismanaged. In fact, the two-year gap in funding NIPP projects under President Yar'adua was due to the intensive legal, political, and financial scrutiny these projects were subjected to with a view to avoid repeating the alleged corruption. Several senior officials of the Rural Electrification Agency and key members of the House of Representatives Committee on Power were arraigned by the Economic and Financial Crimes Commission for alleged embezzlement of NG $\$ 6$ billion funds belonging to the Rural Electrification Agency. For a long time during the stage of the privatization process that involved reaching a settlement the erstwhile staff of $\mathrm{PHCN}$, there were allegations that the workers' pension fund of around NG $\$ 88$ billion, accruing from the 7.5 per cent deductions from their salaries, was misappropriated.

The current 8th National Assembly has set up a 13-man Senate Committee to probe the power sector reform, based on real, perceived, and alleged corruption involving fiscal appropriation during the power sector reform and the entire privatization process, especially the PHCN unbundling, from President Obasanjo to date. Also being probed is MHI's management of the 
TCN. It is estimated that approximately US $\$ 29.635$ billion $^{6}$ has been spent on the power sector in the past 16 years with very limited results. While the outcome of this probe is expected, one hopes it does not end up like previous attempted probes of the same issue in 2007 by the House of Representatives and Senate that degenerated into claims and counter-claims of witch-hunting. One key finding of the investigatory committee was the discovery of around 2,500 containers of imported power equipment worth approximately US $\$ 5$ billion abandoned at the Lagos ports with accumulated demurrage of over NG $\$ 4$ billon. In the end, in 2010, the chairmen of both committees were accused by the Economic and Financial Crimes Commission of involvement in a NG $\$ 5.2$ billion contract scam related to the Rural Electrification Project.

\subsection{Regulatory, institutional, and legal framework}

There was an inherent structural weakness in the institutional framework for power sector reform. ${ }^{7}$ These institutional weaknesses emanate from obvious gaps, overlaps, confusion, and conflicts in the mandates and interactive relationships among these institutions as provided for in their enabling laws. In many cases, the issue of what institution is responsible for playing a coordination and leadership role in the power sector is obscure. For example, NAPTIN-a power sector capacity-building institution-is also mandated to oversee effective monitoring of and compliance with the technical and operating standards. Yet, this mandate is also given to the Standards Organization of Nigeria and the National Environmental Standards and Regulations Enforcement Agency, thus revealing a conflict of mandate among these institutions.

A recent development with respect to possible conflicts in the power sector involves the establishment of the Nigerian Electricity Management Services Authority at the twilight of President Goodluck Jonathan's administration in May 2015. The new agency is mandated to carry out inspections of electrical materials throughout the entire electricity supply industry, and to enforce all statutory technical electrical standards, testing and certification, and regulation of all electrical installations and instruments. In addition, the agency is given the power to ensure that all major electrical materials and equipment used in Nigeria are of the right quality and standards, as well as to specify technical standards for electrical plants, electric lines, and connectivity.

This mandate obviously conflicts with that of the Standards Organization of Nigeria. Moreover, it also distorts the regulatory structure and framework of the power structure hitherto, where NERC was solely responsible for both the economic and technical regulation of the sector. The mandate of the agency - to promote measures for advancing the skills of those working in the power sector and to issue competency certificates and licences to qualified electrical personnel and contractors-also conflicts with that of NAPTIN. Creating additional regulatory agencies is inconsistent with the philosophy of privatization and negates the provision in Section 32 of the EPSRA. The possible over-regulation and confusion bred through this development may hinder effective functioning of the sector, thus dampening efficiency of performance through increased bureaucracy.

\footnotetext{
${ }^{6}$ It is estimated that Presidents Obasanjo, Yar'adua and Jonathan spent US\$16 billion, US\$5.375 billion and US\$8.26 billion, respectively.

${ }^{7}$ See Appendix 3 for a comprehensive list of institutional players in the power sector reform.
} 
Nigeria has a high potential for clean energy that remains largely untapped and underutilized. For instance, the country's potential in technically exploitable large-scale hydropower is estimated to be more than 10,000, MW with the capacity to produce about 36,000 GWh of electricity annually with only 15 per cent of this developed as at 2012 (FMoP 2015). Added to this are the small and medium hydropower potentials, capable of generating 3,500 MW with less than 2 per cent exploited. Yet, hydropower generation is one of the cleanest and cheapest means of power generation. As Nigeria's economy is primarily an agrarian one, the large by-products from organic non-fossil biological materials offer additional potential for biomass energy. Nigeria is situated in a high sunshine belt, with well-distributed sunshine in all parts of the country and solar radiation varying between $12.6 \mathrm{MJ} / \mathrm{m}^{2}$-day (megajoule per square metre per day) in the coastal areas to $25.2 \mathrm{MJ} / \mathrm{m}^{2}$-day in the far north. Despite the country's wealth of geothermal, wave, and tidal energy resources, these are not in use at all at the moment and have been largely ignored in the power sector reform process.

The Draft National Energy Policy developed by the Energy Commission of Nigeria in 1993 and reviewed in 1996 made some references to the importance of renewable energy for the country. These earlier documents were further revised through the National Energy Policy of 2003. These laid the foundation for a more specific focus that culminated in the Renewable Energy Master Plan 2005 followed by the Renewable Electricity Policy Guidelines in 2006. The general objective of the Renewable Energy Master Plan is to enunciate a national vision, targets, and a roadmap for addressing the energy supply challenge facing the country by expanding access to energy through accelerated development and exploitation of renewable energy (ECN 2005). The key focus was on establishing a comprehensive policy framework, technology, human resources, infrastructure, market instruments and legal instruments required for evolving an efficient national energy supply mix focusing more on the renewable energy system. Hydro, biomass, solar, and wind are the major sources of renewable energy considered in this policy document.

Despite these interventions, renewable and clean energy has yet to gain much traction in Nigeria's power sector reform and development. The lack of traction results from challenges that put renewable energy and energy efficiency at economic, regulatory, or institutional disadvantages relative to other forms of energy (FMoP 2015). Key among these challenges are regulatory, institutional, and political bottlenecks that limit the extent to which investments could be attracted to these important activities. Specifically, the Roadmap for Power Sector Reform focuses mainly on the development of conventional grid-based electricity that is urban in focus, and mainly non-renewable due to considerations of scale and cost among others. Rural areas that are close to the urban centres on the national grid have the prospect of benefitting from the extension of the national grid through the power sector reform. Off-grid rural areas that cannot be so accommodated will have to depend on alternative solutions, prominent among which is non-renewable energy.

To correct this lopsidedness and ensure development of both on-grid and off-grid rural-focused electricity, a non-renewable energy development strategy is required. This need was satisfied through the NREEEP that was recently approved by the country's Federal Executive Council in April 2015. The general purpose of this policy is to ensure a coordinated, coherent, and comprehensive renewable energy policy that will help drive hydropower, biomass, solar, and wind as sources of energy in Nigeria. Specifically, the policy seeks to achieve the following: improve inclusive access to modern and clean energy resources, and promote energy security; increase the proportion of renewable energy in the overall energy mix with a view to meeting or exceeding the ECOWAS (Economic Community of West African States) renewable energy targets; pursue achievement of key potentials in renewable energy that include energy savings, 
job creation, improved industrial competitiveness, and lower air pollution; set national targets for renewable electricity generation for the country; and initiate a framework for action plans, collaborations, and sustainable financing that would help to achieve the renewable energy objectives of the country.

The policy takes cognizance of the current state of technology in the country by focusing on hydropower, biomass, solar, wind, geothermal, wave, and tidal energy power plants, and cogeneration plants for energy production. It also outlines critical elements for successful development of renewable energy. These include: constant revision of the percentage share of renewable energy in the country's energy generation mix in a target year through mandatory or voluntary renewable portfolio standards; generation disclosure requirement; incentivization of renewable energy generation through power production tax credit; provision of incentives through favourable renewable electricity pricing by adopting feed-in tariffs and other benefits that include tax exemptions and holidays, capital grants, subsidies, and other similar incentives; establishment of a Public Benefits Fund through which a percentage of the tariff is devoted to supporting renewable power generation projects; and establishment of a net metering framework. The policy framework also set short- (2,438 MW) medium- (8,188.2 MW) and longterm $(23,134.8 \mathrm{MW})$ targets for renewable energy generation.

Several political economy issues limit the extent to which the renewable energy targets can be met. Prominent among these are policy, institutional, regulatory, business environment, financing, standards and quality, and limited advocacy. First, government policies on power generation and utilization have focused mainly on conventional energy sources, with renewable energy largely excluded because renewable energy sources are more expensive compared to nonrenewables. Hence, subsidies, tax rebates, and other incentives have for a long time been highly disproportionate, with less focus on renewable energy. Excessive involvement in, and overregulation of the sector by the government for a very long time is also an inhibiting factor. Until recently, the power sector was completely controlled by the government-owned entity that was the sole body responsible for energy generation, transmission, and distribution. The entity was both the sole player and self-regulator in the sector. While this has changed with the ongoing power sector reform, more open and less discriminatory access to the national grid is important to stimulate investment in renewable energy. Also important is the need to reduce investment risks by assuring improved institutional, legal, and market frameworks for PPAs.

Second, public advocacy with a view to raising public awareness on the relative benefits of renewable energy is highly limited. For example, some hold the view that solar panels are highly radioactive and cause cancer. This completely untrue view emanates from information asymmetry about solar panels. Therefore, solar energy service providers have to battle with this wrong perception to make any meaningful market penetration. On the other extreme are those who think this form of energy generation is meant for more mature and advanced economies. Ultimately, these views distort the market and further discourage renewable energy generation and utilization. Solving this problem is incumbent on all stakeholders, but the government has to take the lead by initiating a coordinated approach that leverages existing information from donor community, civil society organizations, non-governmental organizations, and organized private sector.

Third, the investment and financing framework for renewable energy is yet weak in Nigeria. It is a fact that while renewable energy is clean, environmentally friendly, and relatively cheap in the long run, its initial set-up costs are high. Thus, at this initial stage, demand for renewable energy may be low due to its high cost, which may be out of reach of most Nigerians. With average electricity cost in Nigeria from conventional sources around US $\$ 0.05 / \mathrm{kWh}$ and solar costing between US $\$ 0.2$ and US $\$ 0.4 / \mathrm{kWh}$, it is obvious that demand for power generation through 
renewable sources would discourage consumption. Worse still is the fact that commercial deposit finance institutions are very wary about lending to long-term renewable energy projects compared to those engaging in the large-scale conventional power ventures. But it is a known fact that investors are interested in profit and will not invest if they are not sure of breakthrough or at least breakeven. Special assistance is needed from the government in this respect through special funds for renewable energy projects, subsidies for households, risk guarantees for renewable energy investors, import waivers for renewable energy equipment, concessional loans for small and medium-sized enterprises in renewable energy business, and tax pioneer status.

Some other challenges that require attention are to do with standardization and quality control of equipment and technology. Nigeria is notorious for importation of low-quality products and equipment, ranging from light manufacturing to heavy equipment. This is the result of weak regulation of standards. The Standards Organization of Nigeria, which has regulatory oversight of this area, should initiate a framework for setting acceptable standards and certifications for renewable energy equipment that is being locally produced or imported to the country. This will instil confidence in actual and potential consumers, and erase the notion that such equipment is not of reliable quality. Renewable energy technology is in its infancy in Nigeria, making the technology less attractive to potential investors.

Regulation and incentive structure are necessary for the effective development of renewable energy in Nigeria through attracting investment from local and foreign investors. Institutional support and coordination are also essential among key stakeholders that cut across all government ministries, departments and agencies, the donor community, and civil society organizations. A clear incentive mechanism also needs to be developed around provision of tax credits to renewable energy producers, importers, and users. A well-defined tax holiday or rebates with a specific exit strategy should be developed to encourage participation in this form of power generation. The policy and legislative framework also needs to be further improved as well as institutional coordination. Prominent in this regard are issues of standards and quality control of equipment. The initial seed for developing renewable energy has been sown through the NREEEP. Following up with effective implementation holds the promise of success.

The interest and support of international donors and finance organizations for renewable energy as opposed to fossil fuel-powered plants should be leveraged in order to promote clean energy in Nigeria. For example, the African Development Bank manages a multi-donor trust fund worth close to US $\$ 100$ million on behalf of the governments of Denmark, the United Kingdom, and the United States and, more recently, Italy. The fund, known as the Sustainable Energy Fund for Africa, seeks to support small- and medium-scale renewable energy and energy efficiency projects in Africa. Similarly, the World Bank manages the Africa Renewable Energy and Access programme with funding worth about US $\$ 30$ million on behalf of the Kingdom of the Netherlands. The Power Africa initiative of US President Barack Obama is a multi-billion dollar initiative aimed at increasing access to reliable, affordable, and sustainable cleaner electricity in Africa. The initiative plans to lift hundreds of millions of Africans out of darkness by adding 30,000 MW of new, cleaner electricity. Taking advantage of such huge interest could help attract significant finance to diversifying energy sources in Nigeria and, more importantly, move towards cleaner energy.

\section{The way forward}

The Nigerian power sector reform was justified on good grounds, including a perennially poor electricity supply and the inefficiency of a state-owned monopolistic power regulator and player with limited capability to drive the needed reform in the power sector. Principally through the 
EPSRA, the Roadmaps for Power Sector Reform and several other policy documents, the reform aims to establish a sustainable power sector and electricity market structure that is competitive and driven by private sector operators. It ultimately aims to provide a lasting solution to the incessant and intractable power supply challenges facing the country.

The reform-one of the most ambitious and comprehensive of its type in the world-aims to find solutions to these challenges. The monopoly structure of the power sector has been dismantled. The sector now has a technical and economic regulator. A bulk electricity trader has been set up to promote effective power purchase among generation and distribution companies. One of the greatest obstacles restraining local and foreign investment entry into the sectorcost-reflective pricing-is being addressed and has reached advanced stage. Relative improvement in power generation and supply to end-users is currently being experienced compared to the pre-reform period.

Laudable as the reform is and commendable as these achievements are, the reform is fraught with several emerging challenges that tend to limit the pace of change and realization of the intended benefits. Prominent among these are: shortage of supply of natural gas and inadequate gas infrastructure to power the completed power plants; policy inconsistencies and somersaults; the existence of a regulatory, institutional, and legal framework that is characterized by overlapping mandates, conflicts, and confusion; inadequate and poorly maintained transmission facilities and infrastructure; inadequate investment in the electricity value chain; weak human capacity to manage the post-reform electricity market; limited focus on renewable and clean energy sources; and a huge metering gap.

Gas is the cheapest way to generate electricity per kilowatt unit of power and Nigeria has this resource in abundance. Formulating an effective gas policy which allows gas to play a pivotal role in the power sector reform is imperative for any meaningful progress to be made. One way this could be done is by encouraging public-private partnership and completely private sector-driven gas development initiatives through sufficiently robust incentives. This will further reduce the pressure on government, given its limited financial resources, to undertake this task alone. Another important area would be to invest more in gas infrastructure that would help evacuate gas and deliver it to the power stations. Stepping up surveillance on the pipeline infrastructure with a view to increasing the probability of apprehending vandals and ensuring timely punishment that would deter vandalism would contribute in no small way to ensuring the security of gas-to-power. Overall, the government needs to be more innovative in solving the lingering challenge of an unstable gas supply to the power stations.

Capable, relevant, and sufficient manpower development for the entire power sector value chain is absolutely necessary to push forward the reform agenda and manage post-privatization challenges. In addition to the required system, electrical, hydro, and mechanical engineers and other technical professionals are required to drive the reform and post-reform process. Unlocking the sector through the reform has opened up the sector to a spectrum of power sector value chain activities that necessitate increased human and technical capacity. The reform has created opportunities in the production and maintenance of transformers, transmission lines, meters, cables of acceptable quality, and other facilities in the entire value chain of generation, transmission, and distribution. The government should ensure that NAPTIN plays its role in this respect by providing it with the needed resource support. Private sector players should complement the government's efforts through NAPTIN by undertaking training and capacity development initiatives.

There is a need to push for production, distribution, and dynamic efficiency in the power sector. This can be achieved only through a well researched, highly insightful, and incisive evaluation, 
assessment, and appraisal of the status quo. Probing the power sector reform through politically motivated committees may not achieve this objective. Rather, a holistic technical and economic assessment that looks at the entire value chain is what is required. For instance, it is not clear if any such study has examined the equilibrium structure of the entire spectrum of the Nigerian electricity industry with a view to determining the demand, supply, and the existing demandsupply gap in the market. More efforts by both public and private stakeholders should be directed towards research and development in alternative sources of renewable and clean energy. Most studies and investigations have focused on supply-side issues, paying little attention to demand-side solutions. There is need to balance the current focus on supply solutions with demand management interventions that will reduce the pressure on demand.

Political will and policy consistency are necessary to improve on the reform and attract more local and foreign investors. One key area in which such political will can be demonstrated is in providing leadership by example in the management of the transmission segment of the power sector value chain. This segment is under the control of the government and yet remains the weakest link in the electricity value chain. Rather than engaging in wanton interference and using it for political gain, the focus should be on providing the needed oversight of the management consultant while at the same time giving it the freedom to carry out its assigned responsibilities as contained in the contract signed. The government should ensure sustained investments in the sector since the transmission company remains under its purview. Given the chequered history of government management of such private business activities, conscious efforts must be made to ensure that the transmission company does not slip into the same state as NEPA and Nigerian Telecommunications (NITEL). Proactive and determined efforts must be geared towards investing in network expansion and completing ongoing transmission projects. The greatest risk to the reform is lack of continuity and commitment resulting from lack of political will.

The government should focus on continuously evolving an effective institutional framework that guarantees sustainability of the reform efforts. High priority needs to be given to the regulatory, institutional, and human capacity framework for managing post-privatization challenges. The plethora of policy pronouncements, documents, committees, commissions, and other frameworks for the power sector reform should be reviewed and properly aligned to suit and reflect current realities. Continued development of the power sector, through laws and regulations, and enforcement of compliance with these in the sector, is also necessary. There is also a need for increased investment in clean and renewable power generation to help the country achieve an optimal mix of energy sources, with the emphasis on hydro and solar power sources and ultimately improve the country's green growth.

Evolving a cost-reflective tariff would result in a win-win situation that would help attract the necessary finance from existing and prospective investors while simultaneously making consumers content that they are getting value for their money. Unnecessary political interference in energy pricing can at best be counterproductive, as demonstrated by the tariff reduction of President Goodluck Jonathan's administration shortly before the presidential elections. NERC's action in reviewing the assumptions for calculating the MYTO 2.1 is in order and should be pursued to a logical end. Consideration for fairness and the public interest in reviewing the tariff is commendable. However, possible loopholes and slippery slopes should be avoided in relation to the issue of aggregate technical, commercial, and collection losses.

It is necessary to develop special-purpose financial products and vehicles that would help channel funds from surplus sectors to the power sector. The Nigerian pension fund and insurance fund are currently estimated to stand at around US\$30 billion and US\$2 billion, respectively. These funds are currently under-utilized and will be of limited benefit to the economy if they are not deployed to sectors of real need such as the power sector. Much needs 
to be done to amend investment rules so that a large part of these resources could be channelled to power generation, especially clean energy and long-term infrastructure projects. Putting the fund into government bonds that are considered to be safe havens would yield limited benefits. The Sovereign Wealth Fund, especially the Infrastructure Fund, should be effectively utilized in deploying innovative power generation, especially clean and renewable energy.

Tackling the current spate of insecurity would also be of obvious help in moving forward on the power sector reform. The north-eastern part of the country is riddled with insecurity occasioned by an insurgency that makes investment in power generation, transmission, and distribution in the region problematic. Moreover, the Niger Delta, the source of the gas needed to power the power plants, also has its fair share of instability. These pose a threat to sustained success of the reform.

Global goodwill and commitment to improve the power sector should be leveraged. In 2013, the US government announced the private sector-focused Power Africa initiative with a commitment to add over 30,000 MW of more efficient electricity generation capacity in six African countries, including Nigeria. The support offered by this initiative is gaining momentum though it has not yet significantly affected choice of power generation technology. In 2014, for example, Power Africa, through USAID’s Development Credit Authority, made available US $\$ 90$ million for on-lending to the newly privatized distribution and generation companies. It also made available US $\$ 50$ million for a portfolio of solar-battery hybrid power systems distribution in Nigeria. Power Africa is supporting NBET to negotiate and finalize a model Power Purchasing Agreement that ensures effective connection of some wind and solar power projects that are capable of delivering $600 \mathrm{MW}$ to the national grid.

More global and continental development finance, foundations, and concessional private sector financing institutions and South-South partners have indicated interest and even made commitments to help improve the power situation in Nigeria. For instance, during the 2014 USAfrica Leaders Summit, the World Bank announced a US\$5 billion commitment in support of the Power Africa initiative. Recently, the African Development Bank has made 'Light and Power Africa' one of its 'High 5s', with a commitment to invest US $\$ 12$ billion in energy projects between 2015 and 2020. From 2015 until 2020, the European Union (EU) is budgeting for around $€ 2.5$ billion in grants and $€ 20$ billion investment in sustainable energy provision in subSaharan Africa. Additionally, individual EU member countries are expected to provide financial support that will more than double this amount, with France committing US $\$ 6.4$ billion over the next four years to electrification in Africa. The US and EU have already committed to providing support through synergy by signing a memorandum of understanding in this respect. SouthSouth partners, notably China, are also making inroads into pepping up activities in the power sector. This enthusiasm for investment, and technical support and assistance, should be effectively leveraged to achieve the desired goals of the power sector reform.

\section{References}

Adenikinju, A.F. (2003). 'Electric Infrastructure Failures in Nigeria: A Survey-based Analysis of the Costs and Adjustment Responses'. Energy Policy, 31: 1519-30.

Adoghe, A.U., A. Odighe, and S.O. Igbinovia (2009). 'Power Sector Reforms: Effects on Electric Power Supply Reliability and Stability in Nigeria'. International Journal of Electrical and Power Engineering, 3(1): 36-42.

Aliyu, A., A. Ramli, and M. Saleh (2013). 'Nigeria Electricity Crisis: Power Generation Capacity Expansion and Environmental Ramifications'. Energy, 61(8): 354-67. 
Amadi, S. (2015). 'From Megawatts to Actual Delivery: Bottlenecks and Solutions'. Lecture Delivered at the NAPE (Nigerian Association of Petroleum Explorationists) Specialized Change Workshop, Lagos, 14 July.

David-West, A. (2014). Nigerian Power Sector: Value Investment Opportunity or Value Trap? UK: CSL Stockbrokers Power Sector Infrastructure Review.

ECN (2005). National Energy Policy: Renewable Energy Master Plan. Abuja: Electricity Corporation of Nigeria.

FMoP (2012). Federal Ministry of Power 2011 Annual Report. Abuja: Federal Ministry of Power.

FMoP (2015). National Policy on Renewable Energy and Energy Efficiency. Abuja: Federal Ministry of Power.

Idris, A., S.A. Kura, M.A. Ahmed, and Y. Abba (2013). 'An Assessment of the Power Sector Reform in Nigeria'. International Journal of Advancements in Research and Technology, 2(2): 1-37.

IEA (2014). African Energy Outlook: A Focus on Energy Prospects in Sub-Saharan Africa. Paris: International Energy Agency.

Joseph, I.O. (2014). 'Issues and Challenges in the Privatized Power Sector in Nigeria'. Journal of Sustainable Development Studies, 6(1): 161-74.

NERC (2015). Amended Multi Year Tariff Order (MYTO) 2.1 for the Period 1 April 2015 to December 2018. Order No. NERC/REG/3/2015. Abuja: Nigerian Electricity Regulatory Commission.

Ochugudu, A.I. and V.A. Onodugo (2013). 'Power Sector Reform Deliverables: How Well and How Good to Customers?' International Journal of Management Technology, 1(1): 1-14.

Okafor, E. (2008). 'Evaluation of the Impact of Power Sector Reform on the Nigerian Economy'. International Journal of Natural and Applied Sciences, 4(4).

Oke, C.A. (2008). 'Resuscitating and Sustaining the Nigerian Power Sector'. Paper presented to the Nigerian Association for Energy Economics (NAEE) at the NNPC Towers, 14 August.

Okoro, O.I. and E. Chikuni (2007). 'Power Sector Reforms in Nigeria: Opportunities and Challenges'. Journal of Energy in Southern Africa, 18(3): 52-7.

Onochie, U.P., H.O. Egware, and T.O. Eyakwanor (2015). 'The Nigeria Electric Power Sector (Opportunities and Challenges)'. Journal of Multidisciplinary Engineering Science and Technology, 2(4): 494-502.

PTFP (2015). 2014 Year in Review. Abuja: Presidential Task Force on Power.

Sanyaolu, H.A. (2008). Electricity Power Sector Reform in Nigeria: Utilising Restructuring and Regulatory Reform as a Means of Achieving a More Efficient and Competitive Sector. An LLM Dissertation. CEPMLP, University of Dundee, UK.

Tallapragada, P.V.S.N and B.S. Adebusuyi (2008). 'Nigeria's Power Sector: Opportunities and Challenges'. In P. Collier, C. Pattillo and C.C. Soludo (eds) Economic Policy Options for a Prosperous Nigeria. New York: Palgrave Macmillan.

TCN (2012) Transmission Company of Nigeria 2011 Annual Report. Abuja: Transmission Company of Nigeria. 
Appendix 1: Successor private power companies in Nigeria

\begin{tabular}{lllll}
\hline Distribution & \multicolumn{3}{c}{ Generation } & Transmission \\
Name & $\begin{array}{l}\text { Customer Base } \\
(2008)\end{array}$ & Name & Installed Capacity (MW) & TCN \\
Abuja & 469,306 & Afam & 776 & 1,320 \\
Benin & 529,341 & Egbin & 1,330 & 1,020 \\
Enugu & 545,103 & Kainji/Jebba & 2,100 \\
Eko & 266,075 & Sapele & 972 \\
Ibadan & 812,000 & Shiroro & \\
Ikeja & 535,692 & Ughelli & \\
Jos & 277,626 & & \\
Kaduna & 285,736 & & \\
Kano & 489,965 & & \\
Port Harcourt & 347,789 & & \\
Yola & $\mathrm{N} / \mathrm{A}$ & & \\
\hline
\end{tabular}




\section{Appendix 2: Key policies driving the Nigerian power sector reform}

2001National Electric Power Policy

2003 National Energy Policy (NEP)

2004 National Economic Empowerment and Development Strategy (NEEDS)

2005 Electric Power Sector Reform Act

2007 National Energy Master Plan (NEMP)

2008 Electricity Master Plan (EMP)

2009 Vision 20:2020

2010 Roadmap for Power Sector Reform

Multi-Year Tariff Order (MYTO 1 and 2)

Grid Codes

2013 National Policy on Renewable Energy and Energy Efficiency (NPREEE)

2005 and 2012 Renewable Energy Master Plan (REMP)

2006 Renewable Electricity Action Programme (REAP)

2006 Renewable Energy Policy Guidelines (REPG)

Industry Incentives for Renewable Energy (IIRE)

2010 National Policy and Guidelines on Renewable Energy

The Renewable Energy Feed-in Tariff (REFIT)

Draft National Operational Framework for Energy Efficiency for Nigeria

2006 Rural Electrification Strategy and Implementation Plan (RESIP)

2009 Rural Electrification Policy Paper (REPP)

2012 National Rural Electrification Strategy and Plan (NRESP)

2013 Rural Electrification Strategy and Implementation Plan (RESIP)

2007 Nigerian Biofuel Policy Incentives

2015 National Policy on Renewable Energy and Energy Efficiency

Appendix 3: Key institutions in the Nigerian electricity sector

Federal Ministry of Power (FMoP) 
Federal Ministry of Science and Technology (FMST)

Federal Ministry of Environment (FME)

Federal Ministry of Water Resources (FMWR)

Federal Ministry of Land, Housing and Urban Development (FMLHUD)

National Planning Commission (NPC)

Nigerian Electricity Regulatory Commission (NERC)

Rural Electrification Agency (REA)

National Power Training Institute of Nigeria (NAPTIN)

Electricity Management Services Ltd of Nigeria (EMS)

Energy Commission of Nigeria (ECN)

National Agency for Science and Engineering Infrastructure (NASENI)

National Environmental Standards and Regulations Enforcement Agency (NESREA)

Nigeria Hydrological Services Agency (NHSA)

Standards Organization of Nigeria (SON)

Nigerian National Petroleum Corporation (NNPC)

Presidential Task Force on Power (PTFP)

Nigerian Gas Company (NGC)

Transmission Company of Nigeria (TCN)

Rural Electrification Agency (REA)

Gas Aggregation Company of Nigeria (GACN)

Electricity generation companies (GENCOs)

Electricity distribution companies (DISCOs)

Nigeria Electricity Liability Management Company (NELMCO)

Nigerian Electricity Management Services Authority (NEMSA) 